\title{
From Individual Empowerment to Social Movement: Drought Management for Ecological Restoration
}

\author{
Fr. Joseph, D'souza SJ, Fr. Siju Varghese SJ \\ Social Centre, Ahmednagar, India \\ *Corresponding Author: socialcentre@rediffmail.com
}

\begin{abstract}
If we believe human life is a gift then we ought to safeguard it. Today this life is at stake from the womb to the tomb. As a result there is imbalance in many aspects of life even in the climatic conditions. At Kankewadi, in Ahmednagar, Maharashtra, where we began community mobilisation work, many people were facing a losing battle. They could hardly see any light at the end of the tunnel. Jesuit Priests responded to this situation through an innovative method known as the Watershed Development Programme which holds an ultimate vision of holistic, people centred development. The 'Social Centre', a philanthropic NGO came into being as a ray of hope to the rural folk in the drought prone Ahmednagar district of Maharashtra. The paper describes the methods adopted to empower people and usher in improvements in the quality of life of the people. The results of the process disturbed social, economic, political and cultural benefits across all sections of the society in Kankewadi and its neighbouring villages. The so-called voiceless people became leaders of the local governing bodies. The social centre's approach of problem solving with participatory ideology has motivated Government institutions to adopt the watershed development. This involves the building of water as a critical resource for community empowerment, livelihood development and also to reduce internal displacement of the poor in India. The results of over 125 villages from this programme have the potential to turn into a movement of development which restores the ecological sanity, tackling both short term goals of poverty alleviation and long term goals of positively retaining people in their native habitat.
\end{abstract}

Keywords Watershed Management, Rural Poverty, Social Action, Social Work, Drought Management

\section{Introduction}

Social work practice is a complex and multi-dimensional process with multifaceted tasks. As a result of the situations and the nature of social problems, various factors, stakeholders, and right processes need to be adopted, so that desired changes can be seen. The social worker, in this position must use various methods of practice. While working with communities, practitioners try methods of community development and organisation with social actions, and thus work towards bringing desired social changes. However when the community is a larger geographical region with specific regional problems; a social movement approach is more effective in bringing the desired change. In order to facilitate mass levels of desired social change, the change agent works with local level community interventions. Achievements are shared with many and in due course others may join voluntarily. Work on similar lines over a number of years allows these small scale achievements to take on a form of social movement; leading to the larger, regional level common problem collectively being solved. But this is a theoretical understanding or academic analysis. In reality, when a philanthropic social worker or activist starts working for communities in distress he/she hardly thinks at this scope. Rather this worker thinks only with great zeal, to help people at risk. It may be with purely charitable concerns, with devotional motives, that he/she starts working. The worker is just busy in finding ways and means at the smallest scale, these small scale interventions becoming clearer with further and broader application. Eventually these initial interventions may lead to a model, strategy or methodology which becomes useful and appreciated by many, perhaps getting rewarded and with the capacity to be universally adoptable. Mostly in social movement formation, word of mouth publicity of the work and the acquisition some followers who join social workers and act collectively to do the work through informal ways and means. Eventually people, groups, institutions get added in the process to bring wider level change. For this wider work, collectives are formed. When social scientists or academicians study these realities, they label this process resulting in the formation of a theory. In this way we can see how hence field practice leads to the development of theory. In this paper, the authors analyse whether the Social Centre's work on watershed development has become a movement and if so then in what form and how? Here a hypothetical assumption is formed i.e. Individual 
empowerment can lead to a social movement which factors in bringing about regional change.

Social movements start when broader level or larger social problems have been witnessed by sensitive people. These committed individuals, with greater commitment and vision, work towards bringing solutions to the problems of life and during the process many are motivated to join the cause. Without having the idea of leading a social movement in mind, in 1966, Fr. Bacher, a Swiss Jesuit priest, with his charismatic leadership in the Ahmednagar district of Maharashtra state of India, was able to lead a collective in the area of Watershed Development and Management. The reach of the process was not limited to the regional level but resulted in bringing in international level stakeholders for the cause. He was not at all aware of the underlying cause of the problem but through the effects of the problem visible on the surface, i.e. large scale school drop outs, led him to understand that the root cause of the problem was indeed, water scarcity. Due to persistent droughts in the rain-fed areas of Ahmednagar district people could not stay in their villages. Firstly, when Fr. Bacher realised that children drop out from school due to lack of water in the community, which resulted from families being forced to migrate for work to enable access to the basic living conditions of life, he came to know that not only domestic water was missing but irrigation water availability was also scarce and this caused many social problems in the lives of the people of Ahmednagar district of Maharashtra, India. To delve deep into the problem Fr. Bacher would cycle every corner of the district during the year 1965-66 and as a result learned and understood various problems which the people were facing; those otherwise could not have been diagnosed simply by knowing the surface level problem of school dropouts in his school. This first-hand experience led Fr. Bacher to take innovative interventions to solve the common community problem. After providing many solutions and help to the people's surface level problems it was understood that some basic fundamental solution to underlying problems must be sought. To get along with piecemeal solutions after 23 years of continuous interventions, with many trials and errors methods finally a sustainable solution was found in the form of Watershed Development and Managements, called the 'Ridge to valley' model,1989, at Pimplegaon Wagha in the Ahmednagar district. Today it has become a National programme for watershed development under National Bank for Agriculture and Rural Development (NABARD)'s support programmes in the country, for regions similar to the geographical and climatic conditions of drought prone areas like Ahmednagar.

Hence this paper explores the possibility of seeing the potential of social work practice to locate itself in the context of individual empowerment leading to broader social movement. This paper portrays to the reader an understanding of the process of interventions performed by the Social Centre in three parts and one case study of Kaknewadi village. This village is one of the 125 villages of the Social Centre's unflinching effort to renew the land and improve lives with similar interventions, for almost five decades of the movement. The Social Centre was formed and established as an NGO by Fr. Bacher in 1966 as an organisation set up to perform various formal interventions for the holistic development of the region.

In the first part this paper explains the pre-intervention scenario of the regions in which social problems exist, the second part elucidates the intervention process and the third part narrates the post-intervention phase with a case study. A case study helps to demonstrate the sustainability of the interventions performed for 8 years of the project in the village and even 14 years after project withdrawal, the flame is still burning in the hearts of the villagers.

\section{Part I - Conceptual understanding of the problem within the context}

\section{Drought although a natural phenomena became the root cause of the Social Problems for the community}

As much as two thirds of the geographical area of the state of Maharashtra can be described as drought-prone and as much as half, semi-arid, with rainfall ranging from $150-750 \mathrm{~mm}$. Most of us understand drought as the prolonged period of dry weather, lack of rain. In working terms, drought may be defined as the non-availability of water, due to dry weather, for human consumption and for agricultural crops which may cause famine. Normally, drought is associated with the quantity of rainfall that occurs over the area. It is said that in a given year, if the area has received only $50 \%$ of the normal rainfall, there is drought. The causes of the drought could be -

1. Failure to rain.

2. Untimely rain.

3. Increased demands due to increased population and increased standard of living.

4. Deforestation which directly affects the groundwater bodies levels.

5. Climate change.

\section{Effects of drought are experienced as}

a. Loss of soil fertility - Due to dryness, the heavy soils become brittle and powdery and eroded away due to wind action, thereby reducing soil fertility.

b. Loss of living resources - Due to shortage of water and fodder, the decline of cattle stock and other dairy animals.

c. Loss of livelihood opportunities - Shortage of employment in agricultural sector leads to heavy deforestation.

d. Deterioration of Natural resources - This could lead to overgrazing which eventually cause soil erosion. 
Famine was a regular recurrence in this part of Maharashtra. It has been experienced at regular intervals even up to this day. The situation was even worse in the case of Ahmednagar district of Maharashtra. The acute drought of the sixties caused havoc in the lives of the Ahmednagar people. It caused starvation and lack of potable water which forced people to leave their villages in large numbers in search of food and water. It triggered many children to drop out of school. Education became a distant dream for these people. Many cattle died due to scarcity of fodder. The ecological system deteriorated causing people to sell whatever they had in order to survive. This resulted in further deterioration both socially and economically. Those who suffered the most in this situation were the small and marginal farmers who were not prepared to take on the nature's fury.

Seeing and being in this deplorable situation, many questions were raised in the young mind of the Swiss Jesuit priest, Fr. Herman Bacher. Even though he came as a missionary to work for the evangelization, his focus was on how to alleviate the sufferings of these unfortunate ones? He believed if possible, any intervention should give them lasting, practical solutions. In the first attempt he provided direct loans and assistance to farmers for digging wells and for the purchase of implements such as water-pumps, engines, lift-irrigation, etc. Soon he realized these measures were not giving the desired result. The situation disturbed Fr. Bacher greatly. He understood that the ground water level had not risen. So, is there a way to increase the percolation? Is there any program which could give sustainable, holistic development for everyone in a village? He researched whether there is a way to stop the rain-water where it fell. After several attempts, trials and experiments, he came up with the innovative idea of watershed development techniques which have been since a source of hope and life to many who were staring at a losing battle.

\section{Local participation}

After the painstaking effort it was not easy to vend this idea among the farmers as they were not familiar the concepts. Unlike our age-old traditions, in this program women had a major role to play. They became part of the decision-making process. They came out from within the four-walls of the kitchen to demand their rights through women's users groups. It restored the lost self-respect and dignity of these women. For the first time in their life they experienced someone listening to their concerns and opinions. Like men, they also have a voice.

\section{Financial Stakeholder ship}

However, the major challenge before Fr. Bacher was how to find financial support for this venture. Initially no banks were ready for it. There was no government program or support for such problems. The next big challenge before Fr.
Bacher was how to make this laboratory tested method available to others. In order to do this there was a need to bring various stakeholders/partners to work for the same cause. Hence there was a need to work at various levels. Important was how to get enough financial support. Fortunately, Fr. Bacher had a few friends in the German Government. They came to visit this project and they became convinced, however the German Government could not give funds directly to the Social Centre as a NGO due to national policy. Hence the German Government approached the Reserve Bank of India (RBI). Then RBI directed NABARD, and then through NABARD to the district cooperative bank of Ahmednagar and then to the Social Centre (from International to national then to state and on to local level). Bilateral funds have come through governmental institutions and hence here RBI-NABARD became the representative institution who could receive the funds and divert them through banks and other financial institutions. Funds were sent to the District Co-operative bank of Ahmednagar by NABARD for the project of the Social Centre. As the Social Centre's deposits were in the same bank, trust and confidence were built at the institutional level and small loans were then able to be given to farmers for taking up new innovations in the project. After the completion of the program, NABARD were convinced of the model, watershed development -"Ridge to Valley" by the Social Centre in the year 1989. Also then with the project at Pimpalgaon-Wagha in Ahmednagar district. Finally, it then became a national level program under the leadership of NABARD. This was a great achievement - to achieve a national level program through years of interventions at local levels, where Indian government's money was hardly used.

Here, the Social Centre in conjunction with Fr. Bacher, worked towards bringing many stakeholders and partners to work on this issue so that larger level interventions and participation could be possible with collectives.

\section{Part II- Individual Empowerment to Social Movement...}

One lighted lamp can spread light to a certain area but if number of lamps are lit jointly then more area can be in brightness. With the same intention, the Social Centre worked towards bringing various institutional linkages from international governments, national institutions, at the state level and local level, to adopt new development agenda on watershed development which is at the core of any developmental issues of the region.

The Social Centre established various institutional networks with some funding from international donors and NABARD for financial stakeholdership, AFPRO for technical studies and the State Govt. of Maharashtra. These networks allowed for the creation of their new stakeholder relationships in watershed development, aimed at bringing regional social change in access the water, could be established. 
Basically, a social movement is an effort made by a group to bring or resist a change in society. In this case, the people are denied their basic right to live. Water is crucial for life and without water there is no life. It means there is also no source for livelihood. Therefore the watershed development program should reach every corner of our country where people have been deprived of this precious gift of nature. In order to realize this dream we need to extend and transfer this knowledge to others. The Social Centre, being a pioneer in this, took the lead and with the help of all the people with goodwill came to share the dream of the Social Centre. Fortunately, it is a national level program today with financial aid from NABARD. Many Individuals/NGOs (for example leaders like Anna Hazare, Popatrao Pawar, etc.) were at some time part of this movement and have replicated this same program in their own villages, both at Ralegan siddhi and Hivrebazar in Maharashtra in Ahmednagar district. They have received awards for their work. Now many program are in place for this same cause throughout the country in partnership with the Government of India. But sadly after years of innovations and intervention program, the situation of drought has not changed much! With its untiring effort the Social Centre has reached out to 125 villages so far, over the last 48 years. Still there is more to be done.

Sometimes it has been observed, that when the program is by the people and for the people, then the strengths are increased and as it becomes a national program of the government, then its effectiveness is questioned. For many reasons, the bureaucracy makes actual hurdles in the process rather than being a help and support. Now there are various models, ways, program from government for the cause; but the use and purpose of it has been lost. And after years of hard work and finding right solutions to prevent droughts' effects, the changes are barely seen and the situation is further deteriorating.

Critically looking at the matter now, the Social Centre might perceive that there is an urgent need to start with a second phase of social movement, where stakeholders need to be conscientisised. They may also need to be educated and trained, correctly to take up the responsibility at the local self-governmental level, so that they can plan to source funds from government to facilitate water self-sufficiency at each of the village. With public-private partnership, where the Social Centre could take up a lead role in transferring the acquired experience based knowledge as NGO, the regional and state governments can take responsibility for providing funds.

So, it could be said that there is a scope for leading a second phase of social movement. Here the Social Centre can partner with Govt. institutions as Nodal NGO for educating, empowering and training people towards the cause. This means that local self-government institutions like grampanchayat, their leaders and government officials could be trained and educated with the right vision and skills for bringing sustainable solutions and thereby facilitating further social change.
The authors of this paper want wider consultation from the experts on the following; - will it be an appropriate approach to lead formal social movement with cooperation of the state government? There are number of government supported programs for various purposes which currently exist. These existing programs, like Hariyali, Jalswaraj (financed by World Bank), IWMP (Agri. Dept.), CAPART and NABARD have their own programs for the cause. These need to be made more user friendly. This may serve the purpose to obtain control, access and availability over water by the communities, which itself is a prime resource.

The second need perceived for the next phase i.e. lack of qualified professional human resource in watershed development and management, is a missing gap at various sectors, both NGOs as well as Govt. sectors. It leads to poor implementation and success of these programs. Thus, there is a need to have a pool of trained, skilled, professionals for the cause. The Social Centre's role could be further perceived as a formal state level training resource centre. Social Centre has experienced staff with perfect skills, developed from field practice. To serve this purpose 'WOTR' an independent NGO was established in this movement by Social Centre to focus more technical aspects of the cause, but its effectiveness of it has become a question. There are number of Community based organisations CBOs, NGOs got formed and took over the work of watershed development but their long term institutional and organisational sustainability remain as a challenge. Funds, right co-operation and networking among stakeholders for the cause again become a missing link. Ironically, all this was a smooth affair when it was voluntary and at a very informal institutional nature.

\section{Part III- Case study of Kaknewadi Watershed Development Project}

\section{Situation prior to watershed - 1992}

In 1986, the state was faced with severe drought, Ahmednagar district was amongst the worst hit. In order to meet people's needs government took up many employment generating activities such as road construction, Nala Bund, etc. The social forestry department carried out afforestation. Besides Govt. Efforts, the Tata Relief Committee worked on the drinking water problem. They were planning to start watershed development, but problems within the organisation put an abrupt end to the work. Meanwhile the Social Centre was working in the Kasare Watershed, which is close to Kaknewadi. While working at Kasare, a few villagers from Kaknewadi came in contact with the Social Centre's staff. They were impressed by the impact of the work. This motivated to them take up the watershed development. Subsequently, villagers approached the Social Centre for help. The Social Centre convened a gram sabha in the village and had a lengthy discussion with regard to the same. The villagers were introduced to the concepts of Shramadan, responsibility sharing, social ban on free 
grazing and tree felling, women's development and the necessity of community participation in the implementation of the program, their duties and responsibilities, etc. The villagers agreed to these conditions and the resolution was unanimously accepted to undertake Watershed program.

Kaknewadi was a very backward village in the Parner taluka of Ahmednagar district. The village is surrounded by hills on all sides. On $5^{\text {th }}$ October 1992, the total area of the watershed of the village consists of 853.90 hectares. The average rainfall is $550 \mathrm{~mm}$. The numbers of households were 157 when the implementation of the watershed program began. The main occupation of the village is agriculture. Besides working on their own fields, most of them worked as labourers in the fields of big farmers or migration to work in the fields outside the village. The younger educated members migrated to big cities in search of jobs. The agricultural activity completely depends on the rain-god. Recurring drought depleted the ground water level. As a result productivity from the farm dwindled. Many villagers left their villages for sustenance. Often they fell into the trap of rich landowners who exploited their situation totally and enslaved them for life.

\section{Project implementation phases( 1992-2000)}

Prior to the start of the Watershed Development Program (WSD) there was only one grocery shop in the village for very basic limited primary needs of food and other essential articles. For any other need the inhabitants had to go to Ahmednagar which is about $45 \mathrm{~km}$ away from the village. There is primary level school up to VII std. the drop-out rate among girls after standard VII is high then they have to go to another village for further education to which parents object. The village was supplied with electricity just before the WSD could begin. It was mainly used for domestic purposes. There were only 5 wells in the village at the beginning of the project and now there is a total of 65 big wells with at least for the year's water supply both domestic and agricultural. During the months of early summer the village was supplied with water for drinking by tankers. It was a very traditional village where the role of women was as confined to household work, cooking and looking after the children, working in their own farms and as agricultural labourers on the farms of big landlords outside the village but only with their husbands. Otherwise they were not allowed to leave the house or to take part in any social gatherings. They were secluded from any social/cultural functions in the village except the celebration of the traditional Hindu feasts. The men opposed and discouraged them from attending any functions/ meetings.

During the project the village women formed a group and steadily continued with small savings and micro-financing scheme. During the sowing season they would approach the Social Centre for loans to buy seeds. With this, the women would make the seeds available in the village at a reasonable rate. In this process of buying and selling of seeds women made profit and paid back the loan they had taken from the Social Centre.

In the implementation of the WSD programme the Social Centre emphasizes on people's participation. As a result, firstly Village Watershed Committee (VWC) is formed. It consists of representatives of the landless, farm labourers, women, backward classes, and people residing in different areas of the village. The idea behind forming this committee is that the people should participate actively in the program and could become active stakeholders of the process. They are the planners, executers, implementers, protectors of the assets created under the program and also the beneficiaries. Secondly, the 'Ridge to Valley' approach i.e. making each and every drop of rain water get percolated in the land so that water table gets charged, thirdly, the voluntary labour (shramadan - contribution through own labours), it may create a sense of belongingness and ownership to the program. Fourthly, collaboration with government agencies so that the people could see more benefits and continue to be linked with government for future development of the village.

\section{After the project withdrawal by Social Centre ( post project phase 2001-2014)}

Authors note, during the field visit for this paper and then from the dialogue with villagers, after 14 years of phasing out; the interventions look sustainable to a great extent. The CBOs formed by the Social Centre during the project are still functioning well. People have become aware of their rights and they demand them. It has provided opportunities for more and assured employment. The availability of fodder is increased hence animal husbandry. Due to this, the milk production has increased. It was heartening to know that eleven farmers of the village came together and started dairy milk collection centre. They contributed nearly Rs 11000/- per share. These farmers now collect 2000 litres of milk daily. Since the inception of the project the Social Centre started convincing them the necessity of having toilets for every house. This village has been awarded as Nirmal gram Puraskar (Sanitation clean village) in 2008-2009 which is a government program. Even though it took seven years to realize this dream it is a proud feeling that even after withdrawal of the project the villagers kept the fire burning which the Social Centre had enkindled in them years ago.

\section{Improvement in the educational status of villagers}

The older generation became aware of the value of education for their children and they started sending them to school. Consequently, every child goes to school. They have well established school building up to $7^{\text {th }}$ std. The Social Centre built two class rooms from the project but the people added four more - two rooms from Zilla Parishad funds and two rooms from MLA fund. 
Earlier villagers were cultivating only Jawari and Bajara staple food, today these villagers have cash crops like vegetables, horticulture plantation of mangoes, pomegranates, chikkoos, etc. As a result they have better economic conditions today. It has resulted in improvement in living standard, e.g. good housing, vehicles etc.

\section{Curtailment of migration}

Migration to the urban and industrial centres in search of livelihood has practically ceased since the landless labourers find work in the village itself and there is more work available for the small and marginal farmers. Now these villagers need other labour-force to work in their farms. With good monsoon most of the farmers take three crops a year.

\section{Stable local governance and leadership}

In the Kaknewadi village, the leaders at local self-government body were elected unopposed continuously for 15 years and still that leadership is found to be functional there. One of the major challenges they face today is the vested interest of some of the individuals with the entrance of political parties in the village. Women are active in the local self-government body, which is one of the major contributions of the project. There is equal female representation and participation in decision-making processes. Women during the project had formed a group comprised of 27 women, which is still active there. Their total saving now is of Rs: 100000/-. They have not taken advantage of the bank facilities yet, from own funds they give loans to members.

There is a remarkable change in the village. The village is free from all kinds of bad habits like gutka, pan, tambaku, alcoholism, smoking, etc. which was surprising to the authors but satisfactory. It is evident in their health status. The Village is clean and tidy. The Village watershed community VWC is still active. The maintenance fund of the project is utilized properly (100000/-). There is a ban on free grazing and felling of trees even today which was taught during the project time. VWC get Rs: $50000 /-$ for supervised grazing per annum. This income is utilized for the welfare of the village. It is very encouraging to see how they take care of the plantation through controlled grazing and banning on felling of trees. Thus, they take responsibility for their own growth and development.

Overall, the authors are satisfied to see the progress the village people have made even after the withdrawal of the project since the year 2000, which shows empowerment happened and is sustained to a great extent. Today it is a model village, many people from the neighbouring villages come to see this transformation. VDC is still very active. Last year new elected body has taken over in the grampanchayat (local governing body). VDC would go for guidance and sharing their success in other villages. As a result some outsiders have purchased their land because of the water availability.

\section{Conclusions}

Prior to writing this paper and after studying the village situations the question frequently arose in the minds of the authors was this - Is Empowerment a onetime event?

As time passes, new social problems emerge due to various reasons such as climate change, e-governance, livelihood, micro enterprises (village industries), etc. New inputs, information, trainings are required to pass over to villages and especially in remote areas which are still disconnected from the mainstream of the society. NGOs may need to step in and keep them in touch with them with specific intervals and could provide required inputs e.g. women have saving group but not yet formed SHGs and so they cannot get linked with present government program and microfinance program of the formal banks. And hence it can be said empowerment is an ongoing process and it needs to be updated so that with the space, the people who become enlightened continue to be better in the future too. Further evidence is that villagers have a dairy but they don't have processing unit with them. A dairy at the village is just a collection centre but has potentials to become a processing centre with value addition. They just collect and a professional milk processer collects from them and does processing, earning nearly double the profit. The profit is taken by outsiders rather than the local farmers. So rural communities remain far from getting control over profit/ resources which belongs to them. Hence with timely continuous interventions, critical inputs are required to be given to the rural people by NGOs/ GOs so that the process of empowering may become a never ending process in the light of new developmental yardsticks.

The third aspect observed is that the new young leadership with good vision is missing in the village. Earlier leadership became old and the young generation does not have any one to get them trained in proper orientation to development. Due to the Social Centre's interventions during the project time, seven to nine adults/ individuals were trained and empowered with collective vision on development so they could lead the village in a harmonious way till now. As a team they took up many ventures in consensus with others but today they are aged and new blood must come up and successfully taking over the leadership is a need. The felt need is found here that the good training inputs are required to new generation- youth so that the continuity for further development and progress could be better assured.

It could also be said that social movement has phases in bringing continual social changes to the larger regional challenges and for the years to come. Due to lack of political will power and poor quality of local / regional political leadership and lethargic developmental bureaucracy fails in reaching out to provide solutions for regional social problems even after having good programs and budgeted funds with them. The scope to lead a second phase of the social movement years of the tested knowledge, experience and the technology for bettering the lives of 
rural people with participatory and democratic collectives seems worthy. But the dilemma is whether it is the responsibility of the NGO or the state to work towards the cause. 